\title{
THE HISTORY OF EDUCATION AND SCIENTIFIC RESEARCH IN BRAZIL
}

\section{ORIGINAL ARTICLE}

FREITAS, Roberto Araujo de Moraes ${ }^{1}$

MARTINS, Priscila Bernardo ${ }^{2}$

FREITAS, Roberto Araujo de Moraes. MARTINS, Priscila Bernardo. The history of education and scientific research in Brazil. Revista Científica Multidisciplinar Núcleo do Conhecimento. 04 year, Ed. 12, Vol. 08, pp. 127-138. December 2019. ISSN: 2448-0959, Access link

in: https://www.nucleodoconhecimento.com.br/education/history-of-education

\section{SUMMARY}

In the current article, the historical transformations of teaching activity in Brazil as well as its participation in academic-scientific research is addressed, considering from the influences arising from inherited religions from Europe to the hallmarks of resources technologies in the hands of domestic users. This moment is marked by the transition between the 20th and 21st centuries, thus representing a rampant revolution in the technological sector, with the Internet being the main tool of communication and research, which resulted in a long process of adaptation. It is necessary to mention the difficulty that there is in the process of isolating the knowledge of his local culture, opinions and experiences of his own and the academic baggage with which a teacher

\footnotetext{
${ }_{1}^{1}$ Postgraduate in teaching in higher education, graduated in Computer Engineering.

${ }^{2}$ Doctorate in progress in Science Teaching. Master's degree in Science Teaching. Specialization in Distance Education: Preparation of materials, tutoring and virtual environments. Specialization in Business Pedagogy. Graduation in progress in Mathematics. Graduation in Human Resources Management. Graduation in Pedagogy.
} 
needs to transmit to the student body, because he must understand that the Brazil records influences of various peoples around the world, which has made us have such a mixed culture. In the midst of so many historical transformations, the teaching activity must have its methodologies constantly recycled. For this reason, this work becomes more arduous as the teacher suffers from the impact of the network on the world, since it is reflected in the productivity and reliability of the results of literary and scientific works. This will forever compromise the relationship between knowledge and information.

Keywords: Technology, research, education, reliability.

\section{INTRODUCTION}

The exercise of teaching has always undergone social changes, especially according to the ideological interests of each region, either because of a religious or political nature. From the history of Brazil, dating from 1500, the influence of Christianity in the first schools of the country, orchestrated by the European institution called companhia de Jesus, is relevant. Over the years, there have been incentive periods as well as neglect for population education levels. This gap is a reality that to this day has not yet been overcome, mainly because it is possible to confer a very low investment in the academic sector as well as in scientific research, even if there are laws that support the sector, in a way.

Law that was born in Brazil Empire, more specifically in the government of D. Pedro I. The aforementioned was called the Law of Guidelines and Bases, a law that has been undergoing, to this day, changes throughout governments, being its most recent version dated 1996. Educational traditionalism, given by libraries, books, articles, editorials, etc., begins to transform at the end of the 20th century with the agglomeration of information on the Internet. This is reflected in the difficulty that teachers and researchers have to this day in adapting to new work trends, because, to the same extent that they facilitate access to information, drastically reduce content reliability. 


\section{THE HISTORY OF EDUCATION AND SCIENTIFIC RESEARCH IN BRAZIL}

\subsection{DISCOVERY AND COLONIZATION}

The first significant records indicators of Brazilian education, in the academic-school sense, are paralleled by the history of the country, from its discovery by the government of Portugal, officially in the year 1500 . Since always, access to information and the way people are created and educated in Brazil have repercussions on how society behaves, because it is manipulated according to the desire of the ruling class. According to Ribeiro (1993), it was not interesting for settlers to allow access to information to the natives, since it was a strategy capable of provoking the shock of divergent cultures and interests between the court and the indigenous population.

The proposal, a priori, was to make individuals of the local mass collaborate with the work blindly and submissively and this objective was architected by Europeans on the foundation of distortion of the cultural and religious identity of the native Brazilian population. For this reason, they barely had access to literacy, and thus their culture was violently tampered with. During this process, several indigenous nations were decimated for not submitting to the Jesuit trial. From Europe, the settlers had the support of the Jesuits to spread Christianity in Brazil as they were doing in several countries through their parent institution, the Society of Jesus. The organization has erected several fundamental education units in Brazil.

Twenty-one years after the arrival of the Jesuits, the Order of the Society of Jesus could already have five elementary education schools, in diverse locations throughout the country, especially in coastal regions: Porto Seguro, Ilhéus, Espírito Santo, São Vicente and São Paulo of Piratininga. With them, three schools: Salvador, Rio de Janeiro and Olinda (ALVES, 2009). Here, the difference between school and school occurs according to the level of education. Therefore, read a school for primary education institutions (First Grade or Elementary School I and II, according to the 
$\mathrm{ldb} / 96$ nomenclature) and a secondary education institutions (Second Degree or High School, according to the nomenclature established by LDB/96).

The Jesuits were responsible for education in Brazil for approximately two hundred years. First, catechizing the Indians, which they called savages. They later founded schools and missions. This process of spreading western teachings followed until the expulsion of the Jesuits in 1759. With this, the educational process entered a period of stagnation. According to Rosa (2014), the Order of the Society of Jesus declined after approximately 200 years of the Portuguese's arrival in Brazil. At the time, Sebastião José de Carvalho e Melo, the Marquis of Pombal, was head of state and international diplomat of Portugal.

There was even an attempt at the 1823 constituent, according to NISKIER (1969) due to the proclamation of independence, to increase the education system, through Article 250 that determined the creation of primary schools in each village, gymnasiums in each district and universities in certain places, but this was only in theory, because the emperor dissolved the constituent and the following year he gave the first Constitution of the Empire and in article 179 said: "primary education is free to all citizens." In 1827, it enacted the General Law that will be the first and only for elementary public education until 1946. D. Pedro II, even though it is considered very cult governs for 49 years, but his projects in the educational sector were timid and without relevance (ALVES, 2009, p. 10).

As a member of the Portuguese elite, he very much bothered him about the rise of the religious social domain of the Order, as it unbalanced the political powers of the government. As a result, on January 22, 1759, the sentence was published that determined the exoneration and denaturalization of jesuits from the territory Portuguese (including Brazil). The situation only changed with the arrival of the Royal Family. During the period of the monarchy, education feels the reflections of the expulsion of the Jesuits. Don Pedro I has ruled for years, but has no news. 


\subsection{SOCIAL INVESTMENTS IN THE EDUCATIONAL SECTOR AND THE INFLUENCE OF PROFESSOR PAULO FREIRE}

Due to the long period that the General Law lasted, the educational sector in Brazil only suffered significant transformations from 1946, after the deposition of Getúlio Vargas, during the period that became known as the Second Republic: when the dictatorship of Vargas came to an end and the Brazilian Republican regime was resumed. In 1948, according to what was determined by the fifth constitution, work began on the Law of Guidelines and Bases, which was promulgated in 1961. Simultaneously with the promulgation of LDB, professor Paulo Freire's Popular Education Method emerged. The Popular Culture Movement, MCP, guided by Paulo Freire himself, had farmers as the first students to go through this experience, being literate from the inside out, through their own work. The results obtained -300 literate workers in 45 days - deeply impressed public opinion.

It was decided to apply the method throughout the national territory, but this time it was supported by the Federal Government. There has been remarkable growth in investments in education since the enactment of LDB. The popularization of Professor Paulo Freire's teaching methods inspired several people and institutions, thus creating new projects and social groups to support the dissemination of training and knowledge. Natal/RN was the first Brazilian city to apply this didactics with the Literacy Campaign "Standing On The Ground Also Learns To Read", aimed at illiterate adults. Alves (2009, p. 67) says that there are also at that time "the Popular Centers of Culture, linked to the National Union of Students; the Grassroots Education Movement (linked to the National Conference of Bishops of Brazil) and the Government of the Union."

In 1962, the Federal Council of Education was created, in compliance with Article 9 of the Law on Guidelines and Bases. This comes in place of the National Board of Education. In the same year, the State Councils of Education, the National Education Plan and the National Literacy Program are created, the latter two by the Ministry of Education and Culture, following the proposal of the Paulo Freire Method. With the creation of this system, Freire inaugurates a new stage in adult education in Brazil. 
This educational project, carried out by the Cultural Extension Service of the University of Recife, under his leadership, called the Paulo Freire Education System, had as main target adult illiteracy. However, after a short time of implementation, these projects were interrupted by the military coup of 1964 . Thus, in the words of Oliveira (2001, p.56):

Until the march 31, 1964 coup, the relationship between progressive governments and popular movements focused on popular education was collaborative. That is, in order to make efforts to implement the proposals of Brazilian populism and developmentalism. Some of the most expressive movements of education and popular culture in Brazil are born there. These are expressions of this movement: the Popular Culture Movement (MCP), the Grassroots Education Movement (MEB), the Popular Center of Culture (CPC), and the "Standing on the Ground" Campaign is also learned to read." From then on, education and culture were no longer due to the simple formation of the electorate. Instruments of transformation of the social structure are considered, as spaces for the formation of conscious, critical and participant beings.

With the military coup in 1964, a strong repression falls on social movements, also taking effect on the groups and institutions that worked on popular education and culture projects. The MEB, however, remained in operation from the National Literacy Program. Between 1970 and 1971, when Brazil, when establishing institutional act No. 05, in the Costa Silva government, entered the most repressive period of the military dictatorship, a period called "coup within the coup". During this period, the government chose to install an even larger structure, the Brazilian Literacy Movement - MOBRAL (Law No. 5. 379 de 15/12/67).

Among its objectives, the dissemination of the official ideology of development was among its objectives, with a view to strengthening the current model of domination and modernization. However, it has been, in the words of Bittar and Bittar (2012, p. 163), that post-dictatorship governments were also unable to solve the problem and, moreover, "for failing to comply with the universalization of the basic school, a task 
carried out by most countries passage from the 19th to the 20th century, Brazil entered the 21st century with this shameful heritage."

\subsection{RESEARCH INCENTIVE INSTITUTIONS}

Also in the early 1960s, part of the government came to see an advantage in investing in technological and scientific development. During this period, Fapesp - São Paulo State Research Support Foundation was created, and with it several other related institutions Brazil within. Among the objectives was the creation of the strictu sensu graduate model. It is also noteworthy the SBPC - Brazilian Society for the Progress of Science, created in 1934, in the city of São Paulo / SP, but which began to have more visibility and autonomy in the transition between the 1960s and 1970s. In 1988 Brazil promulgated its new constitution, known as the Citizen Constitution, whose article 208 establishes that it is the duty of the State to guarantee compulsory and free elementary school.

[...] it was an important historical milestone in Brazilian education, since this law restructured school education, reformulating the different levels and modalities of education. [...]triggered a process of implementing reforms, policies and educational actions $r[\ldots .$.$] ather than curbing the$ private expansionist process and resetting the directions of higher education, contributed to the exact opposite: it expanded and instituted a diversified and differentiated system, through, above all, access mechanisms, academic organization and courses offered. In this context, he created the so-called sequential courses and university centers; established the figure of universities specialising by the field of knowledge; implemented Centers for Technological Education; replaced the vestibular with selective processes; ended the minimum curricula and relaxed the curricula; created technology courses and higher education institutes, among other amendments (BITTAR; BITTAR, 2012, p. 165).

It is also worth reiterating, a few years later, the policies adopted in both mandates of the government of President Fernando Henrique Cardoso encouraged, mainly, the 
growth of enrollment in Brazilian public schools. It was a policy that aimed to attract more students from elementary school to high school. On the other hand, the State stopped prioritizing, therefore, higher education, which automatically resulted in the lack of resources and also incentives. This negative situation resulted, then, in the early retirement of teachers as well as occasioned higher incidences in their transfers to equivalent private sectors. In this context, the government began the elaboration of a new version for the Guidelines and Bases Act of 1996.

\subsection{BETWEEN ACADEMIC ENCYCLOPEDIAS AND VAST INTERNET CONTENT FOR SCIENTIFIC RESEARCH}

Research has been a common practice in schools since the 1960s, with the proposal to transform students into actors in their educational process. However, research alone does not guarantee the critical development of students and depends on the pedagogical practice guided by the teacher. Garcia (2017) states that the research process was facilitated exponentially after the domestication of microcomputers and the internet. But this meant some disorders for science and the school-academic environment: the discardability of information. A lot of information is not always synonymous with much knowledge. Since information can be achieved in a few clicks, interest in learning has declined. Until then, the exercise of doing a school work required much more effort, since the student should devote a few hours in a library, looking in numerous books for the information desired.

To facilitate the process, there were encyclopedias that presented various themes, later sold by issues in newsstands. Currently, the internet has been the largest source of data for school research. This began from the commercialization of microcomputers in home environments, which were not long before having access to the network (FERRARESI et al, 2009). Until then, universities and school institutions maintained the culture of encouraging research to what was available in books, encyclopedias, scientific articles, etc. To this day, teachers face great difficulty adapting their work to current technological resources, since the Internet is an environment constantly expanding and transforming. Since the number of cyber users grows exponentially 
across the planet and considering that they all enjoy the ease of producing and extracting content from the network, using the internet as a source of research for academic work requires a lot Care.

It is worth noting that the itself was created, at first, for academic purposes. The academic-scientific environment is concerned with the degree of credibility given the information extracted from the network. Due to the proposed immediacy, linked to the new culture of electronically instant communication, the percentage of students and researchers who still make use of library books, printed articles and the like for the writing of their theses is minimal. In any case, universities generally followed with the determination to keep their libraries up to date. The internet did not alter the credibility of the books, so these continued to be the most highly regarded in the search for information. Ferraresi et al (2009, p. 4) claims that:

Study and search activities via online communication are carried out from search sites, with a predominance of search site Google (...). And among the sites that the interviewees know (...) universiabrasil, ibge and schoolar.google are more cited.

At this new moment, Ramos and Copolla (2009) summarize that the academic environment must live up to the Technological Age, adapting their indoor environments to this reality. The internet can be used for various purposes and trainees must be trained to obtain concise and reliable information from it, given its fragility, since any user can produce content. It should be done an analysis work in order to verify the Internet as whether or not it is a pedagogical tool, according to the user's objectives at a given time. They state that the internet within the reach of the home user allows to break down classroom barriers and shorten distances between the teacher and the student, if he cannot or does not want to depend on a fixed schedule, and thus education benefits the collectivity.

(...) the internet (...) has become a potentially infinite source of information and has brought different types of advantage and new problems to the teacher, because while enabling much more 
sophisticated and even more interesting pedagogical interventions that traditional classes (...), lead the teacher to face changes in power relations over knowledge: where the teacher ceases to have control over the reference content and, starts to manage unpredictable information (...). For this reason, for the use of these tools in education, it should not be limited to teacher training as another technological innovation (RAMOS; COPOLLA, 2009, p. 7).

It encourages the ability to self-learning, but should not be adopted as a panacea, as it had been done with the textbook until then. It means that as much as technological resources are being brought into academic reality, they cannot be understood as the only possible work tool for the execution of activities, but results in dynamism and creativity as well as establishes a connection between the theoretical concepts and the private life of each of the students. The Internet is an infinite source of information and this causes the teacher to lose the image of information holder. It is therefore necessary to take some care when dealing with this information.

\subsection{THE ROLE OF THE TEACHER IN THE METHODOLOGICAL TRANSFORMATIONS OF THE ACADEMIC ENVIRONMENT}

It is indisputable that the teaching profession becomes flexible as the structure of the whole society becomes depending on its cultural traditions and resources available for work. The human being, in modernity, drives his work in order to make all sectors of society connected. For this reason, the good teacher should relax his work seeking constant renewal of what he has to offer, aiming at increasing the performance and quality of the service, admitting that including new tools to the reality of the classroom can bring aspects Positive. In this context, Ramos and Copolla (2000, p. 9), allude, in their study, that:

The teacher takes a new attitude. Although, once or again, he still plays the role of specialist who has knowledge and/or experiences to communicate, more often he will play the role of advisor to the activities of the student, consultant, facilitator of learning of someone who can 
collaborate to boost student learning, will play the role of those who work as a team, together with the student, seeking the same objectives: a word, will develop the role of pedagogical mediation.

The computerization of teaching alone is not enough to produce knowledge. The teacher is, first of all, a transmitter of knowledge. He must use all his academic baggage to instill interest in the student for research. It is known that the Internet, when used properly, is a source of knowledge. However, when used indiscriminately and without guidance it can represent a disservice to information. Academic work in which the student uses only the worldwide computer network as a source of research for writing their work can result in innocuous work. At this point, we notice the importance of the teacher's presence, because he should awaken, in the student, the curiosity to go beyond a simple reading on Wikipedia.

The faculty team of the academic environment itself disapproves of the use of certain websites for the acceptance of the essays of its students in their scientific articles, since information, when published on the Internet, becomes very easy to be tampered with, given the ease with which a connected user also produces content. On the other hand, this new scenario brings with it moments of imbalance in his work, since the student is no longer stuck only to the content presented to him, but can also appear with questions other than the plot of the class, based on content available on the internet. For Ramos and Copolla (2000), the teacher is an agent who must constantly seek the updating and recycling of his knowledge baggage.

(...) training should always consider the educational context in which the teacher is inserted, so that he incorporates it into his making known and discussing the use of these technologies is necessary. Allowing each teacher, within their reality of training and acting, to consciously incorporate these tools and, not as simple apparatus to animate or illustrate their classes (RAMOS; COPOLLA, 2000, p. 12).

It is known that technologies involve processes that are improved dynamically and uninterruptedly, causing their users, and especially their developers to engage in order 
to keep up with the transformations that have occurred. In the academic environment, in general, it is not essential that teachers care about the architecture of development of technological resources, but it is interesting that it knows how to concatenate these resources to the reality of the classroom so that students feel immersed in information society, even if they are in the academic-school environment. Immerseing the lesson in a virtual reality brings students a practical view of the topics addressed and makes them more critical when presented properly. If the teacher achieves the goal of developing creativity, curiosity and interaction in students, they will make better use of the content.

\section{FINAL CONSIDERATIONS}

Presenting as a starting point the history of education in Brazil was important to delimit the influences of its people in the interest to academic research. Although legislated, Brazilian education has undergone few investments in research and education since forever and this is due to political interests. Professor Paulo Freire even tried to leave his contribution and reverse the tragic picture of illiteracy in Brazil. The same was referenced internationally and applauded by the great nations and universities, but

Here the project was destroyed and much criticized. In the 21st century, the teacher sees difficulty in adapting to the new trends of society with regard to the Internet, replacing libraries and editorials and reducing the credibility of the authorship of the work, since the act of teaching is not directly linked with the technological universe, but this is what globalizes all sectors of society and at work.

\section{REFERENCES}

ALVES, W. L. U. A história da educação no Brasil: da Descoberta à Lei de Diretrizes e Bases de 1996. 2009. 76 f. Monografia (Especialização em Metodologia do Ensino Superior) - Centro Universitário Católico Salesiano Auxilium. Lins, 2009. 
BITTAR, m; BITTAR, M. História da educação no Brasil: a escola pública no processo de democratização da sociedade. Acta Scientiarum Education, v. 34, n. 2, p. 157168, 2012.

FERRARESI, A. C. et al. Uso da internet como fonte de pesquisa entre universitários: um estudo de caso. In: XIII Encontro Latino Americano de Iniciação Científica e IX Encontro Latino Americano de Pós-Graduação - Universidade do Vale do Paraíba, 2009

GARCIA, R. Antes do Google e da Wikipédia - as enciclopédias do passado. 2017. Disponível em: https://vejasp.abril.com.br/blog/memoria/antes-do-google-e-dawikipedia/. Acesso em: 17 dez. 2018.

OLIVEIRA, E. S. Diferentes sujeitos e novas abordagens da educação popular urbana. 2001. 152 f. Dissertação (Mestrado em Educação) - Universidade Federal Fluminense. Niterói, 2001.

RAMOS, M; COPOLLa, N. C. O uso do computador e da internet como ferramentas pedagógicas. PDE. 2009. Disponível em: http://www.diaadiaeducacao.pr.gov.br/portals/pde/arquivos/2551-8.pdf. Acesso em: 17 jan. 2019.

RIBEIRO, P. R. M. História da educação escolar no brasil: notas para uma reflexão. Paiadéia, n. 4, p. 15-30, 1993.

ROSA, T. F. lluminismo e a expulsão dos jesuítas do Império Português; as reformas pombalinas e o plano dos estudos menores. Revistas de História Regional, v. 19, n. 2, p. 361-383, 2014.

Submitted: August, 2019.

Approved: December, 2019. 